Acta Crystallographica Section B

Structural

Science

ISSN 0108-7681

\section{Anatoly A. Udovenko* and Natalia M. Laptash}

Institute of Chemistry, Far Eastern Branch of RAS, Pr. Stoletiya 159, 690022 Vladivostok, Russian Federation

Correspondence e-mail: udovenko@ich.dvo.ru

\title{
Orientational disorder and phase transitions in crystals of $\left(\mathrm{NH}_{4}\right)_{2} \mathrm{NbOF}_{5}$
}

Ammonium oxopentafluoroniobate, $\left(\mathrm{NH}_{4}\right)_{2} \mathrm{NbOF}_{5}$, was synthesized in a single-crystal form and the structures of its different phases were determined by X-ray diffraction at three temperatures: phase (I) at $297 \mathrm{~K}$, phase (II) at $233 \mathrm{~K}$ and phase (III) at $198 \mathrm{~K}$. The distorted $\left[\mathrm{NbOF}_{5}\right]^{2-}$ octahedra are of similar geometry in all three structures, with the central atom shifted towards the $\mathrm{O}$ atom. The structure of (I) is disordered, with three spatial orientations of the $\left[\mathrm{NbOF}_{5}\right]^{2-}$ octahedron related by a jump rotation around the pseudothreefold local axis such that the disorder observed is of a dynamic nature. As the temperature decreases, the compound undergoes two phase transitions. The first is accompanied by full anionic ordering and partial ordering of the ammonium groups (phase II). The structure of (III) is completely ordered. The $\mathrm{F}$ and $\mathrm{O}$ atoms in the structures investigated were identified via the $\mathrm{Nb}-X(X=\mathrm{O}$ and $\mathrm{F})$ distances. The crystals of all three phases are twinned.

\section{Introduction}

Noncentrosymmetric materials are a fertile topic of research owing to the important physical properties that may be observed in such materials: pyroelectricity, ferroelectricity, piezoelectricity or second harmonic generation (SHG). The first challenge one encounters in synthesizing a nonsymmetric material based on the $\left[M^{\mathrm{V}} \mathrm{OF}_{5}\right]^{2-}(M=\mathrm{V}, \mathrm{Nb}, \mathrm{Ta})$ or $\left[M^{\mathrm{VI}} \mathrm{O}_{2} \mathrm{~F}_{4}\right]^{2-}(M=\mathrm{Mo}, \mathrm{W})$ anions is to prevent oxide/fluoride ligand disorder around the transition metal. The second is to prevent these anions from crystallizing in a centrosymmetric arrangement (Marvel et al., 2007). In the $\left[\mathrm{NbOF}_{5}\right]^{2-}$ anion, out-of-center 'primary' electronic distortion arises from metal $d \pi$-oxygen $p \pi$ orbital interactions. The $\mathrm{Nb}$ atom moves from the center of its coordination octahedron toward the $\mathrm{O}$ atom, forming a short $\mathrm{Nb}-\mathrm{O}$ bond and a long trans $\mathrm{Nb}-\mathrm{F}$ bond (Izumi et al., 2005). Secondary distortions are largely dependent on anion interactions with the extended bond network. $\mathrm{O} / \mathrm{F}$ ordering in a noncentrosymmetric space group has been achieved with the $\left[\mathrm{NbOF}_{5}\right]^{2-}$ anion in inorganic-organic hybrid compounds with cluster (Heier et al., 1998) and chain motifs (Norquist et al., 1998). In inorganic solid-state environments, the individual $\mathrm{Nb}-\mathrm{O}$ and $\mathrm{Nb}-\mathrm{F}$ bonds were recently found (Marvel et al., 2007) to be ordered in noncentrosymmetric $\mathrm{KNaNbOF}_{5}$, which exhibits the SHG property. Among the inorganic series $A_{2} \mathrm{NbOF}_{5}[A=\mathrm{Li}$ (Galy et al., 1969), $\mathrm{Na}$ (Stomberg, 1984), K (Pinsker, 1966) or Cs (Fourquet et al., 1973)], all compounds crystallize in centrosymmetric space groups with disordered oxide and fluoride ions.

In the present work the structures of $\left(\mathrm{NH}_{4}\right)_{2} \mathrm{NbOF}_{5}$ at room temperature and after two phase transitions are reported, with
Received 10 March 2008

Accepted 9 July 2008 
Table 1

Crystal and experimental data for $\left(\mathrm{NH}_{4}\right)_{2} \mathrm{NbOF}_{5}$.

\begin{tabular}{|c|c|c|c|}
\hline & $297 \mathrm{~K}$ & $233 \mathrm{~K}$ & $198 \mathrm{~K}$ \\
\hline \multicolumn{4}{|l|}{ Crystal data } \\
\hline Chemical formula & $\mathrm{F}_{5} \mathrm{NbO} \cdot 2 \mathrm{H}_{4} \mathrm{~N}$ & $\mathrm{~F}_{5} \mathrm{NbO} \cdot 2 \mathrm{H}_{4} \mathrm{~N}$ & $\mathrm{~F}_{5} \mathrm{NbO} \cdot 2 \mathrm{H}_{4} \mathrm{~N}$ \\
\hline$M_{r}$ & 239.99 & 239.99 & 239.99 \\
\hline Cell setting, space group & Orthorhombic, $C m c 2_{1}$ & Monoclinic, $C 2$ & Monoclinic, $I a$ \\
\hline Temperature (K) & $297(2)$ & $233(2)$ & $198(2)$ \\
\hline$a, b, c(\AA)$ & $5.9915(3), 14.4518(8), 7.1999(4)$ & $14.4051(9), 5.9715(3), 7.2312(3)$ & $14.3384(14), 5.9804(6), 14.4524(14)$ \\
\hline$\beta\left({ }^{\circ}\right)$ & 90.00 & $90.195(3)$ & $90.110(3)$ \\
\hline$V\left(\AA^{3}\right)$ & $623.42(6)$ & $622.02(6)$ & $1239.3(2)$ \\
\hline$Z$ & 4 & 4 & 8 \\
\hline$D_{x}\left(\mathrm{Mg} \mathrm{m}^{-3}\right)$ & 2.557 & 2.563 & 2.573 \\
\hline Radiation type & Mo $K \alpha$ & Mo $K \alpha$ & Mo $K \alpha$ \\
\hline$\mu\left(\mathrm{mm}^{-1}\right)$ & 1.97 & 1.97 & 1.98 \\
\hline Crystal form, color & Sphere, colorless & Sphere, colorless & Sphere, colorless \\
\hline Crystal size (mm) & $0.32 \times 0.32 \times 0.32$ & $0.32 \times 0.32 \times 0.32$ & $0.32 \times 0.32 \times 0.32$ \\
\hline \multicolumn{4}{|l|}{ Data collection } \\
\hline Diffractometer & Bruker SMART 1000 CCD & Bruker SMART 1000 CCD & Bruker SMART 1000 CCD \\
\hline Data collection method & $\omega$ scans & $\omega$ scans & $\varphi$ and $\omega$ scans \\
\hline Absorption correction & Multi-scan & Multi-scan & Multi-scan \\
\hline$T_{\min }$ & 0.572 & 0.571 & 0.570 \\
\hline$T_{\max }$ & 0.572 & 0.571 & 0.570 \\
\hline $\begin{array}{l}\text { No. of measured, independent and } \\
\text { observed reflections }\end{array}$ & $8132,1881,1806$ & $8132,3062,3003$ & $16431,6354,5715$ \\
\hline Criterion for observed reflections & $I>2 \sigma(I)$ & $I>2 \sigma(I)$ & $I>2 \sigma(I)$ \\
\hline$R_{\text {int }}$ & 0.028 & 0.025 & 0.025 \\
\hline$\theta_{\max }\left({ }^{\circ}\right)$ & 39.0 & 39.0 & 39.0 \\
\hline \multicolumn{4}{|l|}{ Refinement } \\
\hline Refinement on & $F^{2}$ & $F^{2}$ & $F^{2}$ \\
\hline$R\left[F^{2}>2 \sigma\left(F^{2}\right)\right], w R\left(F^{2}\right), S$ & $0.017,0.049,1.08$ & $0.019,0.052,1.14$ & $0.023,0.057,1.05$ \\
\hline No. of reflections & 1881 & 3062 & 6354 \\
\hline No. of parameters & 61 & 84 & 165 \\
\hline $\mathrm{H}$-atom treatment & Not refined & Not refined & Not refined \\
\hline Weighting scheme & $\begin{array}{l}w=1 /\left[\sigma^{2}\left(F_{o}^{2}\right)+(0.0301 P)^{2}+\right. \\
\quad 0.0923 P], \text { where } P=\left(F_{o}^{2}+2 F_{c}^{2}\right) / 3\end{array}$ & $\begin{array}{l}w=1 /\left[\sigma^{2}\left(F_{o}^{2}\right)+(0.0261 P)^{2}+\right. \\
\quad 0.3566 P], \text { where } P=\left(F_{o}^{2}+2 F_{c}^{2}\right) / 3\end{array}$ & $\begin{array}{l}w=1 /\left[\sigma^{2}\left(F_{o}^{2}\right)+(0.0199 P)^{2}+\right. \\
\quad 1.2051 P], \text { where } P=\left(F_{o}^{2}+2 F_{c}^{2}\right) / 3\end{array}$ \\
\hline$(\Delta / \sigma)_{\max }$ & 0.040 & 0.020 & 0.108 \\
\hline$\Delta \rho_{\max }, \Delta \rho_{\min }\left(\mathrm{e} \AA^{-3}\right)$ & $0.57,-0.41$ & $0.99,-0.97$ & $0.89,-1.28$ \\
\hline Extinction method & SHELXL97 & SHELXL97 & SHELXL97 \\
\hline Extinction coefficient & $0.1814(17)$ & $0.1807(13)$ & $0.02053(17)$ \\
\hline Absolute structure & Flack (1983) & Flack (1983) & Flack (1983) \\
\hline Flack parameter & $0.0(2)$ & $0.0(3)$ & $0.11(10)$ \\
\hline
\end{tabular}

Computer programs used: SMART (Bruker, 1998), SAINT (Bruker, 2000), SHELXTL (Sheldrick, 2008).

a preference for noncentrosymmetric space group in all three cases. The compound has been known for more than 140 years and it was described by Marignac (1866) for the first time, but its structure has not been determined until now.

\section{Experimental}

\subsection{Synthesis}

$\left(\mathrm{NH}_{4}\right)_{2} \mathrm{NbOF}_{5}$ was synthesized in a single-crystal form as colorless transparent tetrahedral prisms or polyhedra, but for the structural determination a spherical crystal was prepared. The starting materials used were of reagent grade. Niobium(V) oxide $(20 \mathrm{~g})$ was dissolved in $50 \mathrm{ml}$ of boiling $40 \%$ hydrofluoric acid in a platinum crucible. The solution was filtered and an $\mathrm{NH}_{4} \mathrm{~F}$ solution $\left(\mathrm{NH}_{4}^{+}: \mathrm{H}_{2} \mathrm{NbOF}_{5}=2.5\right)$ was added. Crystals were formed following slow evaporation in air. Analysis calculated for $\left(\mathrm{NH}_{4}\right)_{2} \mathrm{NbOF}_{5}: \mathrm{NH}_{4} 15.0, \mathrm{Nb} 38.7, \mathrm{~F}$ $39.6 \%$; found: $\mathrm{NH}_{4}$ 15.0, $\mathrm{Nb} 38.3, \mathrm{~F} 39.4 \%$.
The ammonia content was determined by the Kjeldahl method with a precision of \pm 0.3 mass \%. Pyrohydrolysis at $673 \mathrm{~K}$ was used for simultaneous determination of the fluorine and metal content. The sample $(0.2-0.4 \mathrm{~g})$ was placed in a $\mathrm{Pt}$ boat and hydrolyzed in superheated steam for $2 \mathrm{~h}$. HF was water absorbed and analyzed by titration with $\mathrm{Th}\left(\mathrm{NO}_{3}\right)_{4}$; the metal was analyzed gravimetrically by weighing $\mathrm{Nb}_{2} \mathrm{O}_{5}$. The precision of the fluorine and metal determinations was \pm 0.5 mass $\%$.

\subsection{X-ray studies}

A single crystal of a spherical shape was glued to the tip of a glass needle with epoxy resin. The diffracted intensities were measured at 297 (I), 233 (II) and $198 \mathrm{~K}$ (III) on a Bruker SMART 1000 CCD diffractometer (Mo $K \alpha$ radiation, graphite monochromator). Scans in $\omega$ with a step size of $0.2^{\circ}$ were performed at three $\varphi$ settings with $2 \theta=-31$ and $-50^{\circ}$ at a detector distance of $45 \mathrm{~mm}$. Exposures of $30 \mathrm{~s}$ per frame were 
Table 2

Selected distances $(\AA)$ and angles $\left(^{\circ}\right)$ for $(\mathrm{I})$.

\begin{tabular}{lllr}
\hline $\mathrm{Nb} 1-\mathrm{O} 1$ & $1.734(1)$ & $\mathrm{Nb} 2-\mathrm{F} 4$ & $1.904(1)$ \\
$\mathrm{Nb} 1-\mathrm{F} 4$ & $2.089(1)$ & $X 1-X 2 \dagger$ & $2.805(1) \times 2$ \\
$\mathrm{Nb} 1-\mathrm{F} 2$ & $1.945(1) \times 2$ & $X 1-\mathrm{F} 3$ & $2.697(2) \times 2$ \\
$\mathrm{Nb} 1-\mathrm{F} 3$ & $1.933(1) \times 2$ & $\mathrm{~F} 4-X 2$ & $2.722(2) \times 2$ \\
$\mathrm{Nb} 2-\mathrm{O} 2$ & $1.735(1)$ & $\mathrm{F} 4-\mathrm{F} 3$ & $2.635(2) \times 2$ \\
$\mathrm{Nb} 2-\mathrm{F} 3 A$ & $2.116(1)$ & $\mathrm{F} 2-\mathrm{F} 2 A$ & $2.702(2)$ \\
$\mathrm{Nb} 2-\mathrm{F} 1$ & $1.952(1)$ & $\mathrm{F} 2-\mathrm{F} 3$ & $2.665(1) \times 2$ \\
$\mathrm{Nb} 2-\mathrm{F} 2 A$ & $1.944(1)$ & $\mathrm{F} 3-\mathrm{F} 3 A$ & $2.855(2)$ \\
$\mathrm{Nb} 2-\mathrm{F} 3$ & $1.915(1)$ & & \\
& & & \\
$\mathrm{O} 1-\mathrm{Nb} 1-\mathrm{F} 2$ & $99.18(6) \times 2$ & $\mathrm{~F} 3 A-\mathrm{Nb} 2-\mathrm{F} 3$ & $89.93(2)$ \\
$\mathrm{O} 1-\mathrm{Nb} 1-\mathrm{F} 3$ & $94.52(5) \times 2$ & $\mathrm{~F} 3 A-\mathrm{Nb} 2-\mathrm{F} 4$ & $81.56(2)$ \\
$\mathrm{F} 4-\mathrm{Nb} 1-\mathrm{F} 2$ & $84.77(6) \times 2$ & $\mathrm{~F} 1-\mathrm{Nb} 2-\mathrm{F} 3$ & $88.49(2)$ \\
$\mathrm{O} 2-\mathrm{Nb} 2-\mathrm{F} 1$ & $98.90(6)$ & $\mathrm{F} 3-\mathrm{Nb} 2-\mathrm{F} 4$ & $87.27(7)$ \\
$\mathrm{O} 2-\mathrm{Nb} 2-\mathrm{F} 2 A$ & $94.33(6)$ & $\mathrm{F} 3-\mathrm{Nb} 1-\mathrm{F} 3 A$ & $95.20(6)$ \\
$\mathrm{O} 2-\mathrm{Nb} 2-\mathrm{F} 3$ & $93.67(4)$ & $\mathrm{O} 1-\mathrm{Nb} 1-\mathrm{F} 4$ & $174.46(9)$ \\
$\mathrm{O} 2-\mathrm{Nb} 2-\mathrm{F} 4$ & $96.70(7)$ & $\mathrm{F} 3-\mathrm{Nb} 1-\mathrm{F} 2 A$ & $165.96(4) \times 2$ \\
$\mathrm{~F} 3 A-\mathrm{Nb} 2-\mathrm{F} 1$ & $82.93(5)$ & $\mathrm{F} 4-\mathrm{Nb} 2-\mathrm{F} 2 A$ & $90.01(6)$ \\
$\mathrm{F} 4-\mathrm{Nb} 1-\mathrm{F} 3$ & $81.64(2) \times 2$ & $\mathrm{~F} 2 A-\mathrm{Nb} 2-\mathrm{F} 1$ & $92.10(5)$ \\
$\mathrm{F} 2-\mathrm{Nb} 1-\mathrm{F} 2 A$ & $87.96(2)$ & $\mathrm{O} 2-\mathrm{Nb} 2-\mathrm{F} 3 A$ & $175.91(5)$ \\
$\mathrm{F} 2-\mathrm{Nb} 1-\mathrm{F} 3$ & $86.82(2) \times 2$ & $\mathrm{~F} 2 A-\mathrm{Nb} 2-\mathrm{F} 3$ & $171.80(5)$ \\
$\mathrm{F} 3 A-\mathrm{Nb} 2-\mathrm{F} 2 A$ & $81.88(2)$ & $\mathrm{F} 1-\mathrm{Nb} 2-\mathrm{F} 4$ & $164.05(8)$ \\
\hline
\end{tabular}

$\dagger X=\mathrm{F}(\mathrm{O})$.

Table 3

Selected distances $(\AA)$ and angles $\left(^{\circ}\right)$ for (II).

\begin{tabular}{lrlrlr}
\hline $\mathrm{Nb} 1-\mathrm{O} 1$ & $1.727(1)$ & $\mathrm{O} 1-\mathrm{F} 2$ & $2.797(2)$ & $\mathrm{F} 1-\mathrm{F} 4$ & $2.569(2)$ \\
$\mathrm{Nb} 1-\mathrm{F} 1$ & $2.122(1)$ & $\mathrm{O} 1-\mathrm{F} 3$ & $2.762(2)$ & $\mathrm{F} 1-\mathrm{F} 5$ & $2.691(2)$ \\
$\mathrm{Nb} 1-\mathrm{F} 2$ & $1.948(1)$ & $\mathrm{O} 1-\mathrm{F} 4$ & $2.701(2)$ & $\mathrm{F} 2-\mathrm{F} 3$ & $2.634(2)$ \\
$\mathrm{Nb} 1-\mathrm{F} 3$ & $1.959(1)$ & $\mathrm{O} 1-\mathrm{F} 5$ & $2.785(2)$ & $\mathrm{F} 3-\mathrm{F} 4$ & $2.804(1)$ \\
$\mathrm{Nb} 1-\mathrm{F} 4$ & $1.917(1)$ & $\mathrm{F} 1-\mathrm{F} 2$ & $2.797(2)$ & $\mathrm{F} 4-\mathrm{F} 5$ & $2.712(1)$ \\
$\mathrm{Nb} 1-\mathrm{F} 5$ & $1.945(1)$ & $\mathrm{F} 1-\mathrm{F} 3$ & $2.689(2)$ & $\mathrm{F} 5-\mathrm{F} 2$ & $2.742(1)$ \\
& & & & & \\
$\mathrm{O} 1-\mathrm{Nb} 1-\mathrm{F} 2$ & $98.9(1)$ & $\mathrm{F} 1-\mathrm{Nb} 1-\mathrm{F} 2$ & $86.7(1)$ & $\mathrm{F} 2-\mathrm{Nb} 1-\mathrm{F} 3$ & $84.8(1)$ \\
$\mathrm{O} 1-\mathrm{Nb} 1-\mathrm{F} 3$ & $96.8(1)$ & $\mathrm{F} 1-\mathrm{Nb} 1-\mathrm{F} 3$ & $82.3(1)$ & $\mathrm{F} 3-\mathrm{Nb} 1-\mathrm{F} 4$ & $92.7(1)$ \\
$\mathrm{O} 1-\mathrm{Nb} 1-\mathrm{F} 4$ & $95.5(1)$ & $\mathrm{F} 1-\mathrm{Nb} 1-\mathrm{F} 4$ & $78.8(1)$ & $\mathrm{F} 4-\mathrm{Nb} 1-\mathrm{F} 5$ & $89.2(1)$ \\
$\mathrm{O} 1-\mathrm{Nb} 1-\mathrm{F} 5$ & $98.5(1)$ & $\mathrm{F} 1-\mathrm{Nb} 1-\mathrm{F} 5$ & $82.7(1)$ & $\mathrm{F} 5-\mathrm{Nb} 1-\mathrm{F} 2$ & $89.5(1)$ \\
$\mathrm{O} 1-\mathrm{Nb} 1-\mathrm{F} 1$ & $174.2(1)$ & $\mathrm{F} 2-\mathrm{Nb} 1-\mathrm{F} 4$ & $165.5(1)$ & $\mathrm{F} 3-\mathrm{Nb} 1-\mathrm{F} 5$ & $164.3(1)$ \\
\hline
\end{tabular}

carried out in groups of 906 frames each. All reflections were indexed in the corresponding unit cells. More details on data collection and reduction are given in Table 1. Data collection, reduction and refinement of the lattice parameters were performed using SMART (Bruker, 1998) and SAINT (Bruker, 2000). All the calculations were performed with $S H E L X T L$ (Sheldrick, 2008). Atomic coordinates and isotropic displacement parameters for all structures are available in the deposited CIF. ${ }^{\mathbf{1}}$ Interatomic distances and angles are listed in Tables 2, 3 and 4 and hydrogen-bond parameters are given in Table 5 .

\subsection{Spectroscopic measurements}

Mid-IR (400-4000 $\mathrm{cm}^{-1}$ ) spectra were collected in Nujol mull using a Shimadzu FTIR Prestige-21 spectrometer operating at $2 \mathrm{~cm}^{-1}$ resolution. FT-Raman spectra of the compound were recorded with an RFS 100/S spectrometer.

\footnotetext{
${ }^{1}$ Supplementary data for this paper are available from the IUCr electronic archives (Reference: BP5012). Services for accessing these data are described at the back of the journal.
}

The $1064 \mathrm{~nm}$ line of an Nd:YAG laser $(130 \mathrm{~mW}$ maximum output) was used for excitation of the sample. The spectra were recorded at room temperature.

\section{Results and discussion}

\subsection{Crystal structure of (I)}

Structure (I) was solved, to a first approximation, by direct methods and refined against $F^{2}$ by the full-matrix least-squares method, with an anisotropic approximation to $R_{1}=0.0367$ by location of the $\mathrm{Nb}$ atom in the special position $(0, Y, Z)$ of the space group $C m c 2_{1}$ (No. 36). Because of the relatively large $R_{1}$ and on the basis of our preliminary ${ }^{19} \mathrm{~F}$ NMR data concerning the reorientation motion of $\left[\mathrm{NbOF}_{5}\right]$ octahedra, it was suggested that the structure of (I) is disordered. Therefore, additional refinement of the structure was carried out by the displacement of the $\mathrm{Nb}$ atom from the special 4(a) position to the general $8(b)$ position; this lowered $R_{1}$ to 0.0316. In accordance with the vibrational spectra of $\left(\mathrm{NH}_{4}\right)_{2} \mathrm{NbOF}_{5}$ (Fig. 1), which show two $\mathrm{Nb}$ states in the structure (the $\mathrm{Nb}-\mathrm{O}$ stretching range contains two bands, at 933 and $912 \mathrm{~cm}^{-1}$ and at 920 and $910 \mathrm{~cm}^{-1}$ in the IR and Raman spectra, respectively), a subsequent refinement with two independent $\mathrm{Nb}$ atoms in special and general positions was performed; this lowered $R 1$ to 0.0197. In these steps, F atoms were assigned, and then the final refinement to $R 1=0.0185$ was made by ligand separation on $\mathrm{O}$ and $\mathrm{F}$ atoms. Atoms $\mathrm{O} 1$ and $\mathrm{F} 1$ are located on one site with different occupation parameters and equal displacement parameters, as are atoms $\mathrm{O} 2$ and F2. A similar procedure was used by Stomberg (1984) to discern the $\mathrm{O}$ and $\mathrm{F}$ atoms in the disordered structure of $\mathrm{Na}_{2} \mathrm{NbOF}_{5}$.

The occupation parameters were refined for atoms $\mathrm{Nb} 1$ and $\mathrm{Nb} 2$, and then the corresponding parameters for the $\mathrm{F}$ and $\mathrm{O}$ atoms were estimated in accordance with these refined values. The value $x=0.39$ (5) of the Flack (1983)
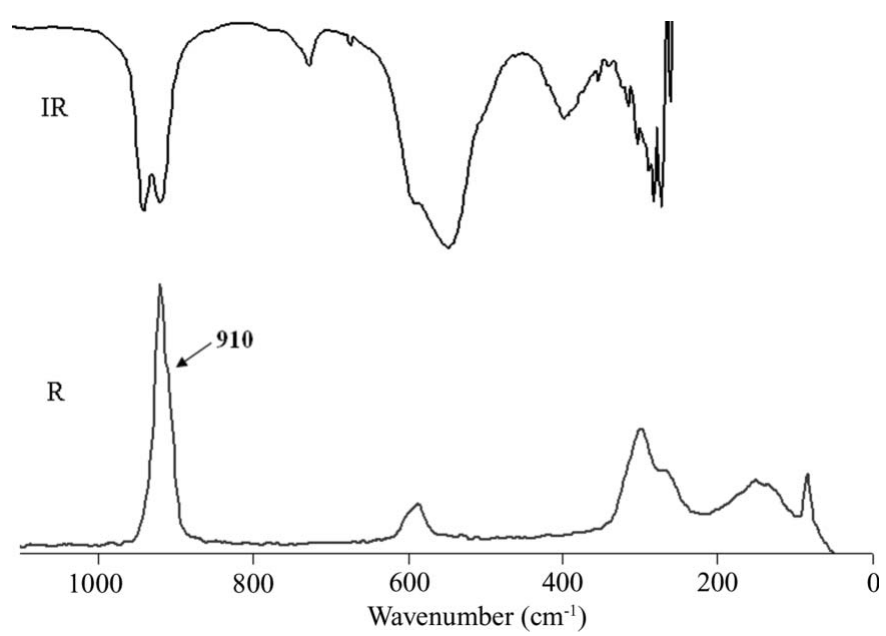

Figure 1

IR and Raman (R) spectra of $\left(\mathrm{NH}_{4}\right)_{2} \mathrm{NbOF}_{5}$ at room temperature. 
Table 4

Selected distances $(\AA)$ and angles $\left({ }^{\circ}\right)$ for (III).

\begin{tabular}{lrlrlr}
\hline $\mathrm{Nb} 1-\mathrm{O} 1$ & $1.721(1)$ & $\mathrm{O} 1-\mathrm{F} 2$ & $2.801(2)$ & $\mathrm{F} 1-\mathrm{F} 4$ & $2.620(2)$ \\
$\mathrm{Nb} 1-\mathrm{F} 3$ & $1.912(1)$ & $\mathrm{O} 1-\mathrm{F} 3$ & $2.715(2)$ & $\mathrm{F} 1-\mathrm{F} 5$ & $2.730(2)$ \\
$\mathrm{Nb} 1-\mathrm{F} 4$ & $1.929(1)$ & $\mathrm{O} 1-\mathrm{F} 4$ & $2.722(2)$ & $\mathrm{F} 2-\mathrm{F} 3$ & $2.676(2)$ \\
$\mathrm{Nb} 1-\mathrm{F} 2$ & $1.934(1)$ & $\mathrm{O} 1-\mathrm{F} 5$ & $2.778(2)$ & $\mathrm{F} 3-\mathrm{F} 4$ & $2.789(2)$ \\
$\mathrm{Nb} 1-\mathrm{F} 5$ & $1.943(1)$ & $\mathrm{F} 1-\mathrm{F} 2$ & $2.719(2)$ & $\mathrm{F} 4-\mathrm{F} 5$ & $2.638(2)$ \\
$\mathrm{Nb} 1-\mathrm{F} 1$ & $2.134(1)$ & $\mathrm{F} 1-\mathrm{F} 3$ & $2.636(2)$ & $\mathrm{F} 5-\mathrm{F} 2$ & $2.707(2)$ \\
$\mathrm{Nb} 2-\mathrm{O} 2$ & $1.737(1)$ & $\mathrm{O} 2-\mathrm{F} 7$ & $2.756(2)$ & $\mathrm{F} 6-\mathrm{F} 9$ & $2.777(2)$ \\
$\mathrm{Nb} 2-\mathrm{F} 10$ & $1.949(1)$ & $\mathrm{O} 2-\mathrm{F} 8$ & $2.839(2)$ & $\mathrm{F} 6-\mathrm{F} 10$ & $2.623(2)$ \\
$\mathrm{Nb} 2-\mathrm{F} 7$ & $1.953(1)$ & $\mathrm{O} 2-\mathrm{F} 9$ & $2.792(2)$ & $\mathrm{F} 7-\mathrm{F} 8$ & $2.663(2)$ \\
$\mathrm{Nb} 2-\mathrm{F} 8$ & $1.954(1)$ & $\mathrm{O} 2-\mathrm{F} 10$ & $2.732(2)$ & $\mathrm{F} 8-\mathrm{F} 9$ & $2.758(2)$ \\
$\mathrm{Nb} 2-\mathrm{F} 9$ & $1.956(1)$ & $\mathrm{F} 6-\mathrm{F} 7$ & $2.639(2)$ & $\mathrm{F} 9-\mathrm{F} 10$ & $2.695(2)$ \\
$\mathrm{Nb} 2-\mathrm{F} 6$ & $2.134(1)$ & $\mathrm{F} 6-\mathrm{F} 8$ & $2.748(2)$ & $\mathrm{F} 10-\mathrm{F} 7$ & $2.832(2)$ \\
& & & & & \\
$\mathrm{O} 1-\mathrm{Nb} 1-\mathrm{F} 2$ & $99.90(5)$ & $\mathrm{F} 1-\mathrm{Nb} 1-\mathrm{F} 2$ & $83.76(5)$ & $\mathrm{F} 2-\mathrm{Nb} 1-\mathrm{F} 3$ & $88.17(5)$ \\
$\mathrm{O} 1-\mathrm{Nb} 1-\mathrm{F} 3$ & $96.56(5)$ & $\mathrm{F} 1-\mathrm{Nb} 1-\mathrm{F} 3$ & $81.13(5)$ & $\mathrm{F} 3-\mathrm{Nb} 1-\mathrm{F} 4$ & $93.13(5)$ \\
$\mathrm{O} 1-\mathrm{Nb} 1-\mathrm{F} 4$ & $96.32(5)$ & $\mathrm{F} 1-\mathrm{Nb} 1-\mathrm{F} 4$ & $80.17(5)$ & $\mathrm{F} 4-\mathrm{Nb} 1-\mathrm{F} 5$ & $85.91(5)$ \\
$\mathrm{O} 1-\mathrm{Nb} 1-\mathrm{F} 5$ & $98.44(6)$ & $\mathrm{F} 1-\mathrm{Nb} 1-\mathrm{F} 5$ & $83.95(6)$ & $\mathrm{F} 5-\mathrm{Nb} 1-\mathrm{F} 2$ & $88.59(5)$ \\
$\mathrm{O} 1-\mathrm{Nb} 1-\mathrm{F} 1$ & $175.64(5)$ & $\mathrm{F} 2-\mathrm{Nb} 1-\mathrm{F} 4$ & $163.47(5)$ & $\mathrm{F} 3-\mathrm{Nb} 1-\mathrm{F} 5$ & $164.99(6)$ \\
$\mathrm{O} 2-\mathrm{Nb}-\mathrm{F} 7$ & $96.46(7)$ & $\mathrm{F} 6-\mathrm{Nb} 2-\mathrm{F} 7$ & $80.31(6)$ & $\mathrm{F} 7-\mathrm{Nb} 2-\mathrm{F} 8$ & $85.94(5)$ \\
$\mathrm{O} 2-\mathrm{Nb} 2-\mathrm{F} 8$ & $100.41(7)$ & $\mathrm{F} 6-\mathrm{Nb} 2-\mathrm{F} 8$ & $84.34(5)$ & $\mathrm{F} 8-\mathrm{Nb} 2-\mathrm{F} 9$ & $89.73(5)$ \\
$\mathrm{O} 2-\mathrm{Nb} 2-\mathrm{F} 9$ & $98.02(7)$ & $\mathrm{F} 6-\mathrm{Nb} 2-\mathrm{F} 9$ & $85.41(5)$ & $\mathrm{F} 9-\mathrm{Nb} 2-\mathrm{F} 10$ & $87.29(5)$ \\
$\mathrm{O} 2-\mathrm{Nb} 2-\mathrm{F} 10$ & $95.51(6)$ & $\mathrm{F} 6-\mathrm{Nb} 2-\mathrm{F} 10$ & $79.82(5)$ & $\mathrm{F} 10-\mathrm{Nb} 2-\mathrm{F} 7$ & $93.07(5)$ \\
$\mathrm{O} 2-\mathrm{Nb}-\mathrm{F} 6$ & $174.11(7)$ & $\mathrm{F} 7-\mathrm{Nb} 2-\mathrm{F} 9$ & $165.41(7)$ & $\mathrm{F} 8-\mathrm{Nb} 2-\mathrm{F} 10$ & $164.07(6)$ \\
\hline
\end{tabular}

Table 5

Hydrogen-bond parameters $\left(\AA,^{\circ}\right)$ in (II) and (III).

\begin{tabular}{|c|c|c|c|c|}
\hline$D-\mathrm{H} \cdots A$ & $D-\mathrm{H}$ & $\mathrm{H} \cdots A$ & $D \cdots A$ & $D-\mathrm{H} \cdots A$ \\
\hline \multicolumn{5}{|l|}{ (II) } \\
\hline $\mathrm{N} 1-\mathrm{H} 1 \cdots \mathrm{O} 1$ & 0.88 & 2.12 & $2.997(1)$ & 177 \\
\hline $\mathrm{N} 2-\mathrm{H} 2 \cdots \mathrm{F} 1$ & 0.86 & 1.89 & $2.721(1)$ & 164 \\
\hline \multicolumn{5}{|l|}{ (III) } \\
\hline $\mathrm{N} 1-\mathrm{H} 1 \cdots \mathrm{O} 1^{\mathrm{i}}$ & 0.80 & 2.15 & $2.921(2)$ & 161 \\
\hline $\mathrm{N} 1-\mathrm{H} 2 \cdots \mathrm{F}^{\mathrm{ii}}$ & 0.90 & 2.04 & $2.908(2)$ & 162 \\
\hline $\mathrm{N} 1-\mathrm{H} 3 \cdots \mathrm{F} 6$ & 0.91 & 2.16 & $2.988(2)$ & 151 \\
\hline $\mathrm{N} 1-\mathrm{H} 4 \cdots \mathrm{F} 1$ & 0.80 & 2.01 & $2.806(2)$ & 171 \\
\hline $\mathrm{N} 2-\mathrm{H} 5 \cdots \mathrm{F} 9$ & 0.84 & 2.07 & $2.862(1)$ & 158 \\
\hline $\mathrm{N} 2-\mathrm{H} 6 \cdots \mathrm{F} 1$ & 0.80 & 2.27 & $3.000(1)$ & 150 \\
\hline $\mathrm{N} 2-\mathrm{H} 7 \cdots \mathrm{O} 2^{\mathrm{iii}}$ & 0.94 & 2.08 & $2.986(1)$ & 174 \\
\hline $\mathrm{N} 2-\mathrm{H} 8 \cdots \mathrm{F}^{\mathrm{iv}}$ & 0.88 & 1.93 & $2.806(1)$ & 170 \\
\hline $\mathrm{N} 3-\mathrm{H} 9 \cdots \mathrm{F}^{\mathrm{i}}$ & 0.87 & 1.91 & $2.762(2)$ & 165 \\
\hline $\mathrm{N} 3-\mathrm{H} 10 \cdots \mathrm{F}^{\mathrm{iv}}$ & 0.89 & 2.22 & $3.030(2)$ & 151 \\
\hline $\mathrm{N} 3-\mathrm{H} 11 \cdots \mathrm{O} 2$ & 0.81 & 2.11 & $2.896(2)$ & 163 \\
\hline $\mathrm{N} 3-\mathrm{H} 12 \cdots \mathrm{F}^{\mathrm{v}}$ & 0.87 & 1.98 & $2.810(2)$ & 157 \\
\hline $\mathrm{N} 4-\mathrm{H} 13 \cdots \mathrm{F} 4^{\mathrm{i}}$ & 0.87 & 2.18 & $3.036(2)$ & 168 \\
\hline $\mathrm{N} 4-\mathrm{H} 14 \cdots \mathrm{F} 8^{\mathrm{vi}}$ & 0.84 & 2.02 & $2.835(2)$ & 166 \\
\hline $\mathrm{N} 4-\mathrm{H} 15 \cdots \mathrm{F} 1$ & 0.84 & 1.94 & $2.683(2)$ & 148 \\
\hline $\mathrm{N} 4-\mathrm{H} 16 \cdots \mathrm{O} 1^{\mathrm{vii}}$ & 0.87 & 2.12 & $2.961(2)$ & 162 \\
\hline
\end{tabular}

Symmetry codes: (i) $x-\frac{1}{2},-y+1, z$; (ii) $x, y-1, z$; (iii) $x+\frac{1}{2},-y+1, z$; (iv) $x, y+1, z$; (v) $x-\frac{1}{2}, y+\frac{1}{2}, z-\frac{1}{2}$; (vi) $x,-y+\frac{1}{2}, z+\frac{1}{2}$; (vii) $x-\frac{1}{2},-y+2, z$.

parameter indicated a possible twin structure of the crystal. For this reason, a final refinement was performed with the twin matrix $\overline{100 / 0} \overline{1} 0 / 00 \overline{1}$, which resulted in $R_{1}=0.0182$. The twin ratio was refined as 0.40 (3):0.60 (3) and $x$ was equal to 0.0 (2).

Structure determinations of (I) were carried out in another two space groups, Cmcm (No. 63) and Ama2 (No. 40), with $R_{1}=0.0201$ and 0.0227 , respectively. It was determined that the noncentrosymmetric space group $C m c 2_{1}$ was preferable because of the lower $R_{1}$ value and the more reasonable $\mathrm{Nb}-X$ distances.

The crystal structure of (I) (Fig. 2) consists of two crystallographically independent disordered ammonium groups and disordered $\left[\mathrm{NbOF}_{5}\right]$ octahedra in which two $\mathrm{F}$ atoms and one $\mathrm{O}$ atom occupy statistically the general $(X 2)$ and special $(X 1)$ positions (Fig. $3 a$ ). The $\mathrm{Nb}$ atom is randomly distributed on the $4(a)$ and $8(b)$ positions, with the probabilities 0.6554 (4) and $0.1723(2)$, respectively. In the $\left[\mathrm{Nb} \mathrm{OF}_{5}\right]$ and $\left[\mathrm{Nb}_{2} \mathrm{OF}_{5}\right]$ octahedra (Figs. $3 b$ and $3 c$ ), the $\mathrm{O}$ atom was identified from the $\mathrm{Nb}-X$ distances (Table 2). In the $\mathrm{Nb} 1$ environment, atom $\mathrm{O} 1$ occupies a special site $X 1$, while it is located at the general $X 2$ site in the $\mathrm{Nb} 2$ environment. The $\mathrm{Nb}-\mathrm{O}$ distances in both polyhedra are equal to $1.733 \AA$, and equatorial $\mathrm{F}$ atoms are displaced from $\mathrm{Nb}$ at $1.90-1.95 \AA$. Niobium is shifted from the equatorial plane toward the $\mathrm{O}$ atom by 0.23 and $0.20 \AA$ for $\mathrm{Nb} 1$ and $\mathrm{Nb} 2$, respectively. It should be noted that a very similar $\left[\mathrm{NbOF}_{5}\right]$ geometry was observed in the fully ordered structures of [4-apy $]_{2}\left[\mathrm{Cu}(4-\mathrm{apy})_{4}\left(\mathrm{NbOF}_{5}\right)_{2}\right]$ (Izumi et al., 2005) and $\left[\mathrm{pyH}^{+}\right]_{2}\left[\mathrm{CuNb}_{2}(\mathrm{py})_{4} \mathrm{O}_{2} \mathrm{~F}_{10}\right]^{2-}$ (Halasyamani et al., 1996). Fig. 3(a) shows that the $\left[\mathrm{NbOF}_{5}\right]$ octahedra have three orientations related by local pseudothreefold axis.

$\mathrm{H}$ atoms in (I) are not localized. Atoms N1 and N2 are surrounded by $11 \mathrm{O}(\mathrm{F})$ atoms in the nearest environment. The electron-density difference maps around the $\mathrm{N}$ atoms (Figs. $4 a$ and $4 b$ ) show the hydrogen electron density to be smeared along the $c$ and $a$ axes for $\mathrm{N}_{1} \mathrm{H}_{4}$ and $\mathrm{N}_{2} \mathrm{H}_{4}$, respectively. Thus, the ammonium groups move in the crystal at room temperature.

\subsection{Crystal structure of (II)}

The structure of (II) was determined and refined in three monoclinic $C$-centered unit cells $(C 2, C m$ and $C 2 / m)$, which were suggested by the BRAVAIS and XPREP procedures which were used in $S M A R T$ (Bruker, 1998) and $S A I N T$

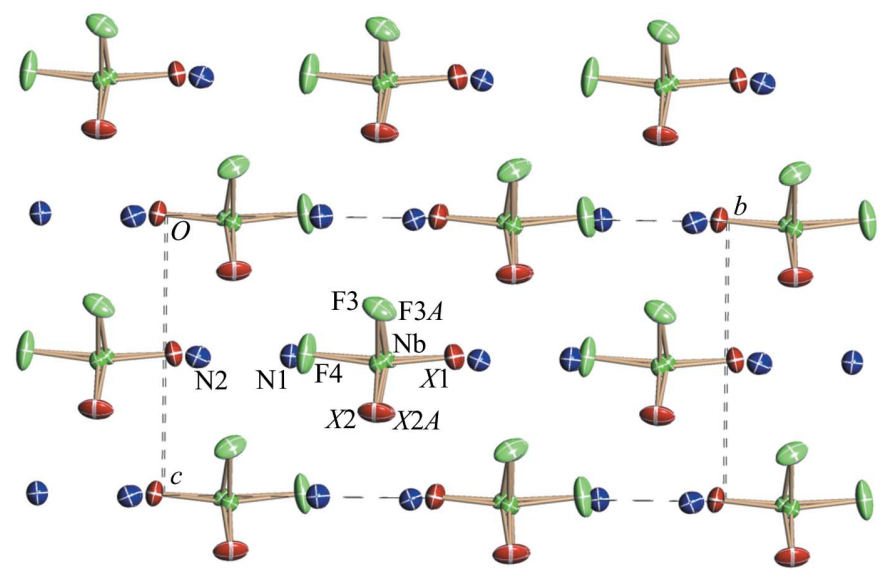

Figure 2

The disordered structure of $\left(\mathrm{NH}_{4}\right)_{2} \mathrm{NbOF}_{5}$ at room temperature (I). 


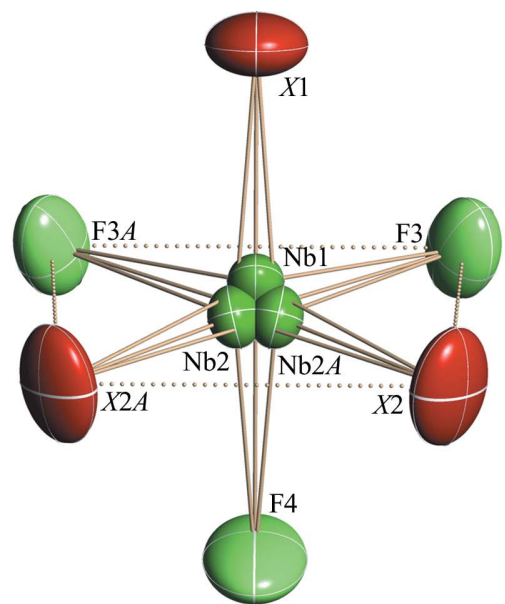

(a)

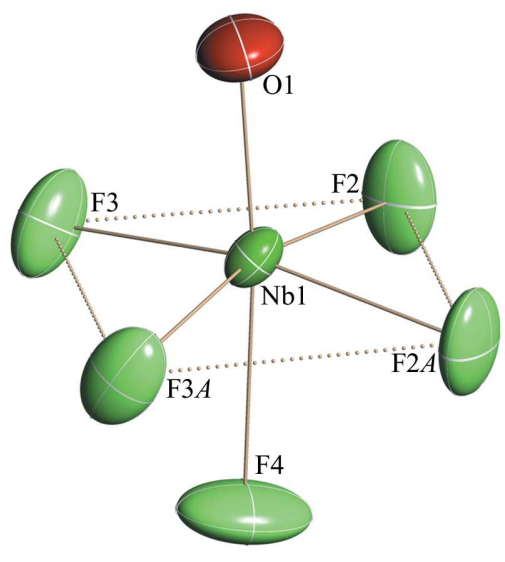

(b)

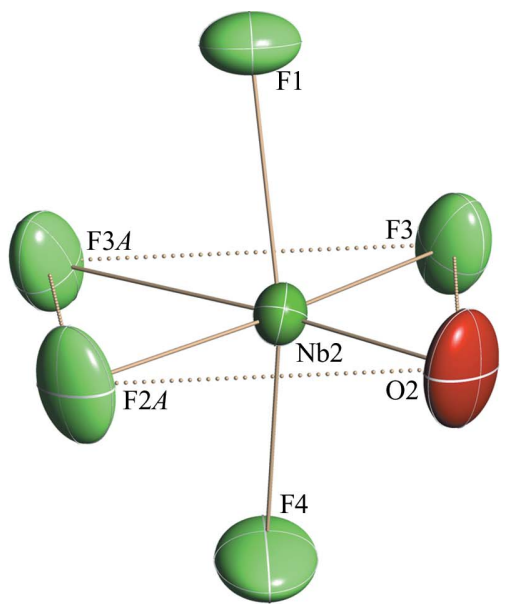

(c)

Figure 3

Some fragments of the structure of (I): the spatial orientations of the $\left[\mathrm{NbOF}_{5}\right]$ octahedron $(a)$; the coordination polyhedra of $\mathrm{Nb} 1(b)$ and $\mathrm{Nb} 2(c)$.

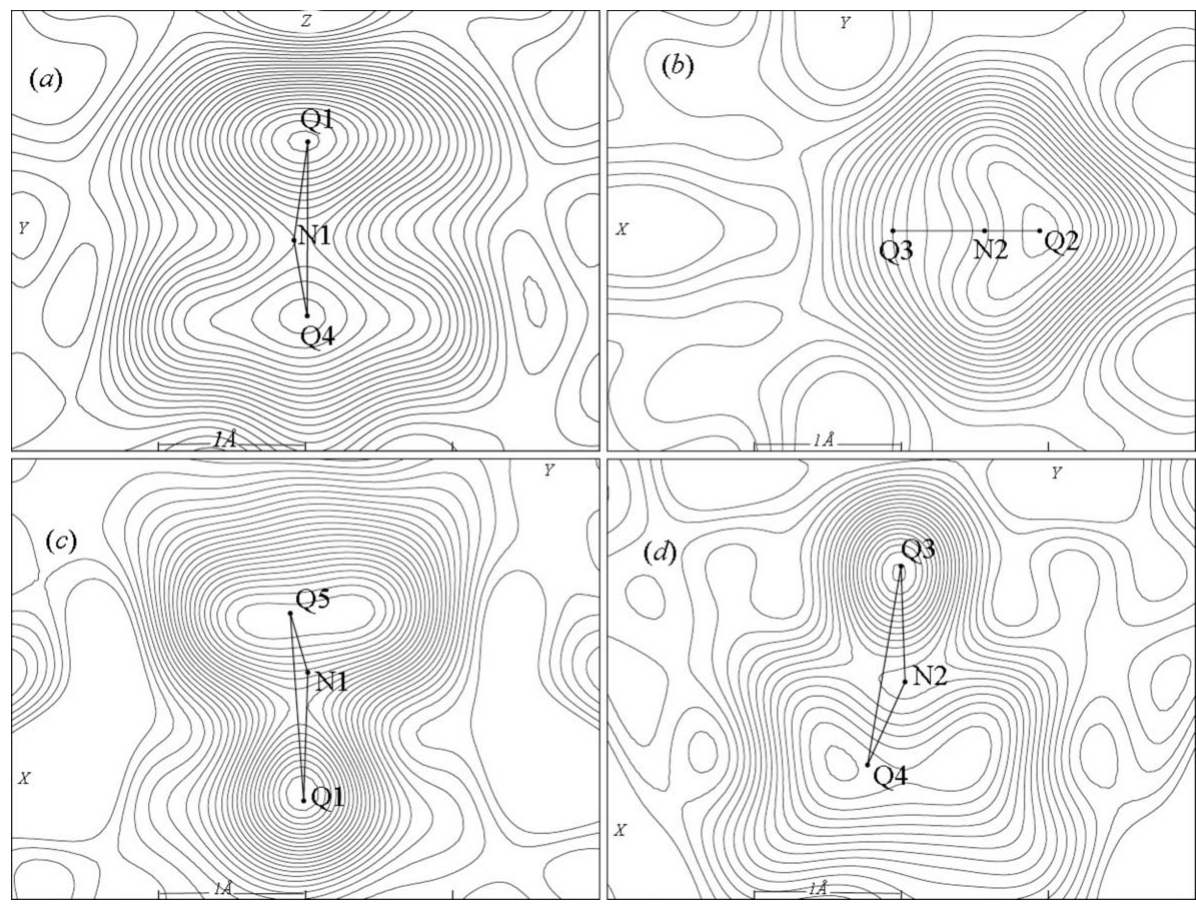

Figure 4

Electron difference densities around $\mathrm{N}$ atoms in (I) $(a, b)$ and (II) $(c, d)$.

a Flack parameter of 0.57 (8), so we rerefined the structure using the twin matrix $\overline{100 / 0} \overline{1} 0 / 00 \overline{1}$ to $R_{1}=0.0191$ with a twin ratio of $0.61(5): 0.39(5)$ and $x$ equal to 0.0 (3).

In the crystal structure of (II) (Fig. $5)$, the $\left[\mathrm{NbOF}_{5}\right]$ polyhedra are identical and fully ordered, corresponding to a single orientational state of the anionic sublattice, i.e. the anions are in a static state. The octahedral geometry in (II) (Table 3) is close to that in (I). The $\mathrm{Nb}$ atom is displaced from the equatorial plane toward the $\mathrm{O}$ atom by $0.25 \AA$. Comparing the structures of (II) and (I), it is clear that the statistical disorder in (I) has a dynamic character. The $\left[\mathrm{NbOF}_{5}\right]$ octahedra are in reorientational motion around the pseudothreefold axis and form three spatial orientations in the crystal, which interchange with one another by a jump around the pseudo-threefold axis. The octahedra stop rotating during the (I) $\rightarrow$ (II) phase transition and their spatial orientations change into one orientation of the $\left[\mathrm{Nb} \mathrm{OF}_{5}\right]$ octahe-

(Bruker, 2000). The corresponding $R_{1}$ values were 0.0193 , 0.0218 and 0.0223 . The $\mathrm{Nb} 1-\mathrm{O} 1$ and $\mathrm{Nb} 2-\mathrm{O} 2$ distances in the case of $C m$ are appreciably different (1.77 and $1.67 \AA$, respectively) - such a significant difference between these values is unacceptable. The octahedral parameters for $C 2$ and $C 2 / m$ are close, but the difference between two $\mathrm{Nb}-\mathrm{F}$ distances and the values of four valence angles are far beyond the limits of $3 \sigma$. However, taking into account that structures (I) and (III) (see below) are noncentrosymmetric, we preferred the space group $C 2$ for the structure of (II). The refinement of (II) in the space group $C 2$ as a single crystal gave dron. Figs. 2 and 5 show that the $\left[\mathrm{NbOF}_{5}\right]$ polyhedra turned around the $b$ axis during this process under the influence of two hydrogen bonds (Table 5).

The electron-density difference synthesis shows that only one of the $\mathrm{H}$ atoms is localized in each ammonium group. These atoms form hydrogen bonds with axial atoms in the octahedron (Table 5). Atoms N1 and N2 are surrounded by 12 and $9 \mathrm{O}(\mathrm{F})$ atoms in the nearest environment, respectively. The electron-density difference maps evidence that the ammonium groups in phase (II) still rotate (Figs. $4 c$ and 4d). 


\subsection{Crystal structure of (III)}

We failed to solve the single-crystal structure of (III) in both triclinic and monoclinic unit cells which were determined by $B R A V A I S$. The structure was solved in the monoclinic group Ia (No. 9) as a two-component twin with the twin law 100/010/ $00 \overline{1}$ and the twin ratio 0.79 (1):0.21 (1). Without taking twinning into account, $R_{1}$ was as high as 0.0529 , many significant large peaks in the difference-Fourier map were observed near the $\mathrm{Nb}$ atoms in a difference electron density map and the $\mathrm{H}$
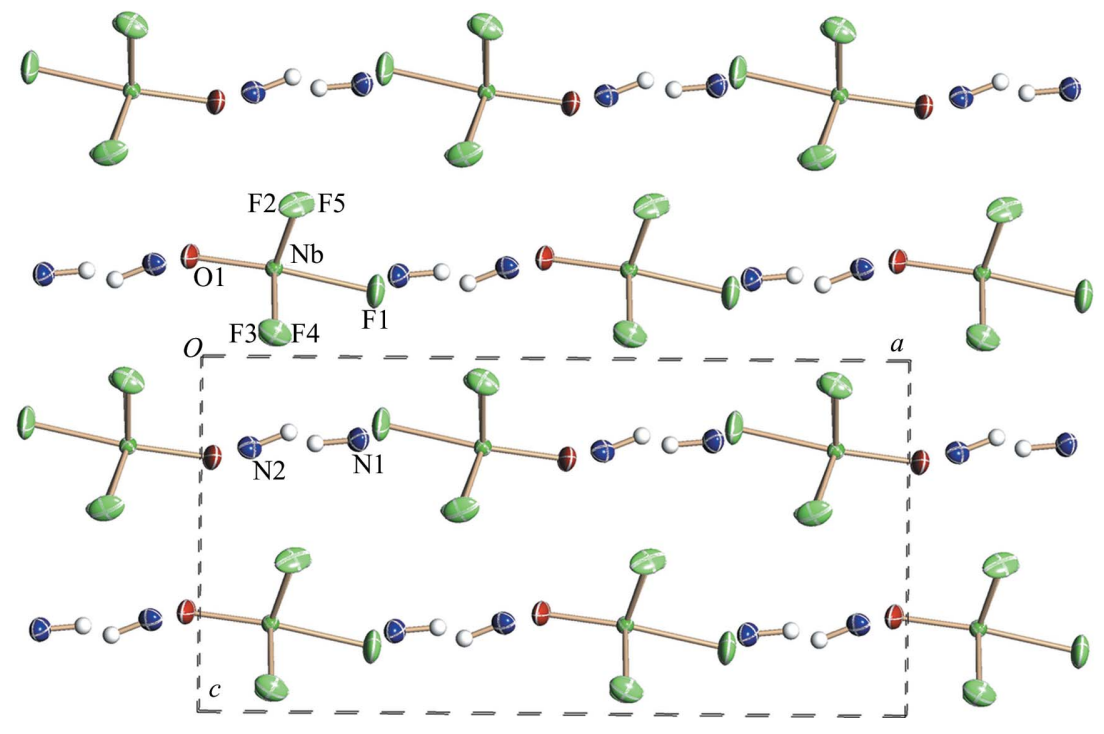

Figure 5

Crystal structure of $\left(\mathrm{NH}_{4}\right)_{2} \mathrm{NbOF}_{5}$ (II) at $233 \mathrm{~K}$ after the first phase transition.

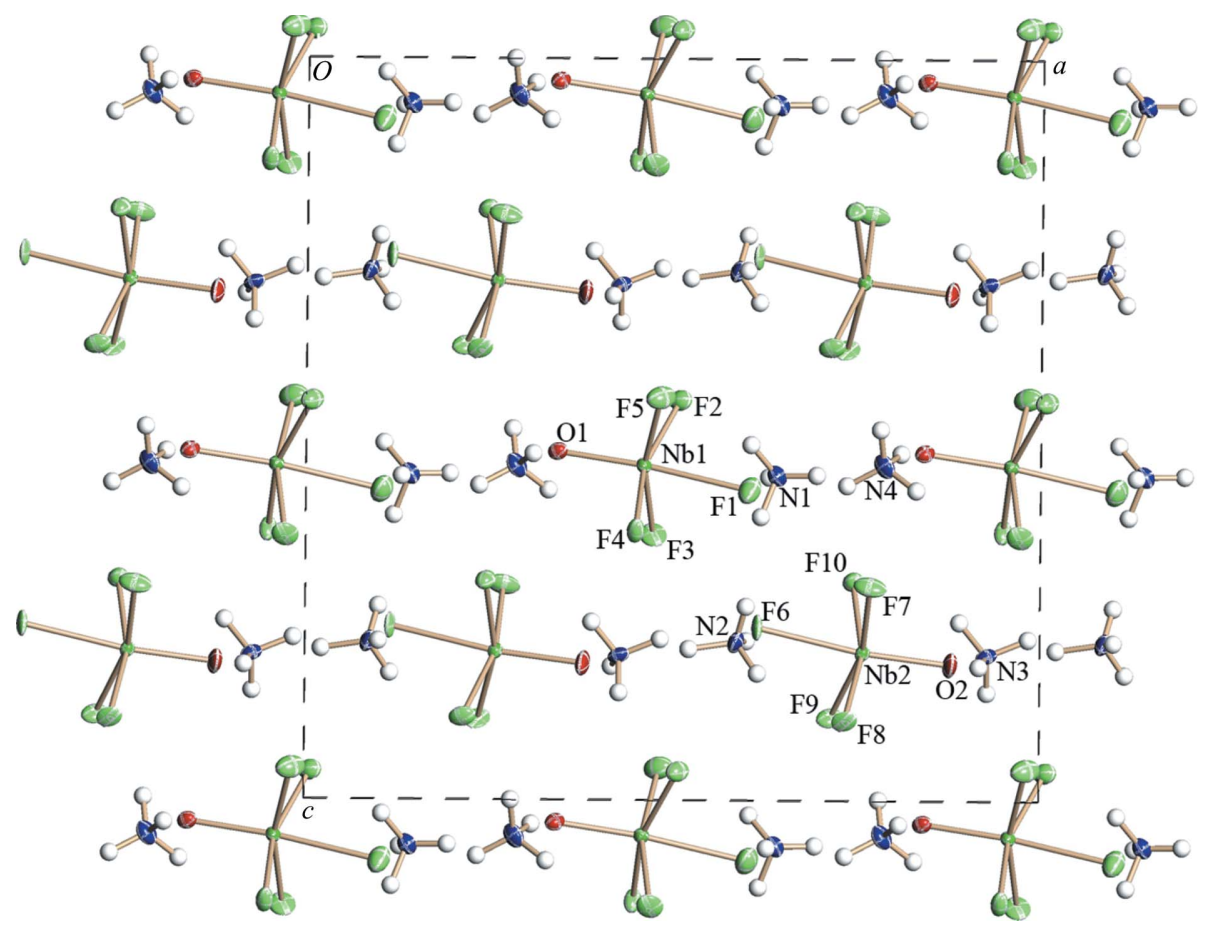

Figure 6

Ordered structure of $\left(\mathrm{NH}_{4}\right)_{2} \mathrm{NbOF}_{5}$ (III) at $198 \mathrm{~K}$ after the second phase transition. atoms were not determined. In the twin model, $R_{1}$ has decreased to 0.0279 and we managed to locate all the $\mathrm{H}$ atoms, whereupon $R_{1}$ dropped to 0.0254 . However, the Flack parameter was $0.5(1)$.

The centrosymmetric space group $I 2 / a$ was recognized to be unsuitable for (III) since structure determination by direct methods and subsequent refinement resulted in a high $R_{1}$ value of 0.134 . Another refinement with initial coordinates previously obtained in $I a$ gave an $R_{1}$ value of 0.0756 and highly weighted large peaks in the differenceFourier map were observed in the electron density difference map. Thus, (III) was confirmed to be noncentrosymmetric. A series of single-crystal structure refinements was resumed in the $I a$ group, resulting in structure inversion. Final refinement with the new twin matrix $\overline{100 / 010 / 001 ~ l e d ~ t o ~} R_{1}$ $=0.0254$ with a twin ratio of $0.21(0): 0.79(0)$ and a Flack parameter of 0.1 (1).

The crystal structure of (III) (Fig. 6) is completely ordered. It contains two types of octahedra: $\left[\mathrm{Nb}_{\left.10 \mathrm{O}_{5}\right]}\right]$ and [Nb2 $\left.\mathrm{OF}_{5}\right]$. Their $\mathrm{Nb}-\mathrm{O}$ vertices are oppositely directed along the $a$ axis. Isolated octahedra are connected via $\mathrm{N}-\mathrm{H} \cdots \mathrm{O}(\mathrm{F})$ hydrogen bonds (Table $5)$. The distances in the Nb2 octahedron are appreciably longer than those in the Nb1 octahedron (Table 4), probably as a result of the influence of hydrogen bonds. As in (I) and (II), the $\mathrm{Nb}$ atoms in (III) are shifted toward the $\mathrm{O}$ atom (by $0.26 \AA$ ). The $\left[\mathrm{NbOF}_{5}\right]$ polyhedra are turned around the $c$ axis during the (II) $\rightarrow$ (III) phase transition under the influence of hydrogen bonds (Table 5), as shown in Figs. 5 and 6.

\section{Conclusions}

It should be noted that no SHG response was observed in $\left(\mathrm{NH}_{4}\right)_{2} \mathrm{NbOF}_{5}$, since all three structures are twinned and appreciably pseudo-centrosymmetric. The comparison of the investigated structures shows that the orientational disorder in (I) has a dynamic nature. Both niobium octahedra and ammonium tetrahedra are reoriented dynamically, so no fixed hydrogen bonds are formed. The three spatial orientations of $\left[\mathrm{NbOF}_{5}\right]^{2-}$ around the pseudo-threefold axis arise from reorientational motion, which forces the central atom to displace 
from the symmetrical position and allows us to identify $\mathrm{O}$ and $\mathrm{F}$ atoms in a separate orientation of the octahedron. Thus, it becomes possible to distinguish between $\mathrm{O}$ and $\mathrm{F}$ atoms by $\mathrm{X}$ ray diffraction under dynamic $\mathrm{O} / \mathrm{F}$ disorder. Changes in the dynamic behavior of the complex are responsible for the phase transitions at lower temperatures.

In (II) two hydrogen bonds are formed and octahedral rotation is absent (rigid anionic sublattice), while the ammonium groups are not fully ordered. After the second phase transition [to (III)], all structural units are ordered.

We thank I. A. Tkachenko for ${ }^{19} \mathrm{~F}$ NMR spectra of $\left(\mathrm{NH}_{4}\right)_{2} \mathrm{NbOF}_{5}$, V. A. Davydov for registration of vibrational spectra and A. N. Pavlov for the SHG experiment. We deeply appreciate the very valuable remarks of a referee, which induced us to revise our results and helped to improve them.

\section{References}

Bruker (1998). SMART, Version 5.054. Bruker AXS Inc., Madison, Wisconsin, USA.
Bruker (2000). SAINT, Version 6.02a. Bruker AXS inc., Madison, Wisconsin, USA.

Flack, H. D. (1983). Acta Cryst. A39, 876-881.

Fourquet, J. L., Jacobini, C. \& de Pape, R. (1973). Mater. Res. Bull. 8, 393-397.

Galy, J., Andersson, S. \& Portier, J. (1969). Acta Chem. Scand. 23, 2949-2954.

Halasyamani, P., Willis, M. J., Stern, C. L., Lundquist, P. M., Wong, J. K. \& Poeppelmeier, K. R. (1996). Inorg. Chem. 35, 13671371.

Heier, K. R., Norquist, A. J., Wilson, C. G., Stern, C. L. \& Poeppelmeier, K. R. (1998). Inorg. Chem. 37, 76-80.

Izumi, H. K., Kirsh, J. E., Stern, C. L. \& Poeppelmeier, K. R. (2005). Inorg. Chem. 44, 884-895.

Marignac, M. C. (1866). Ann. Chim. Phys. 8, 5-44.

Marvel, R., Lesage, J., Baek, J., Halasyamani, P. S., Stern, C. L. \& Poeppelmeier, K. R. (2007). J. Am. Chem. Soc. 129, 1396313969.

Norquist, A. J., Heier, K. R., Stern, C. L. \& Poeppelmeier, K. R. (1998). Inorg. Chem. 37, 6495-6501.

Pinsker, G. Z. (1966). Kristallografiya, 11, 741-748.

Sheldrick, G. M. (2008). Acta Cryst. A64, 112-122.

Stomberg, R. (1984). Acta Chem. Scand. A, 38, 603607. 